\title{
PENGARUH MODEL PEMBELAJARAN SIKLUS BELAJAR BERBASIS TRI HITA KARANA TERHADAP HASIL BELAJAR IPA SISWA KELAS V DI GUGUS IV KECAMATAN BANJAR
}

\author{
${ }^{1}$ Sang Ayu Putu Indrayani, ${ }^{2} \mathrm{Gst}$. Ngurah Japa,${ }^{3} \mathrm{Ni}$ Wayan Arini \\ 1,2,3 Jurusan Pendidikan Dasar Universitas Pendidikan Ganesha \\ e-mail:ayu.putu.indrayani@undiksha.ac.id, igustingurah.japa@undiksha.ac.id, \\ niwayan.arini@undiksha.ac.id
}

\begin{abstract}
ABSTRAK
Masalah dalam penelitian ini adalah rendahnya hasil belajar IPA siswa dilihat dari hasil UTS siswa yang tergolong rendah. Penelitian ini bertujuan untuk mengetahui pengaruh yang signifikan model pembelajaran Siklus Belajar berbasis Tri Hita Karana terhadap hasil belajar IPA siswa kelas V di Gugus IV Kecamatan Banjar Kabupaten Buleleng tahun pelajaran 2018/2019. Rancangan penelitian yang digunakan adalah Non-equivalent Posttest-Only Control Group Design. Populasi penelitian adalah seluruh siswa kelas V SD di Gugus IV Kecamatan Banjar yang berjumlah 166 orang. Sampel diambil dengan teknik random sampling. Sampel penelitian ini adalah siswa kelas V SD Negeri 8 Banjar yang berjumlah 28 orang sebagai kelompok eksperimen dan siswa kelas V SD Negeri 1 Banjar yang berjumlah 24 orang sebagai kelompok kontrol. Data hasil belajar dikumpulkan menggunakan tes pilihan ganda dan penilaian sikap menggunakan lembar observasi. Data yang diperoleh dianalisis dengan menggunakan statistik deskriptif dan statistik inferensial (uji-t). Hasil analisis uji-t terhadap hasil belajar menunjukkan bahwa $t_{\text {hitung }}$ sebesar $4,92, t_{\text {tabel }}$ pada taraf signifikansi 0,05 sebesar 2,00. Hasil penelitian menunjukkan bahwa terdapat pengaruh yang signifikan model pembelajaran siklus belajar berbasis tri hita karana terhadap hasil belajar IPA siswa kelas V di Gugus IV Kecamatan Banjar Kabupaten Buleleng tahun Pelajaran 2018/2019.
\end{abstract}

Kata kunci: hasil belajar, siklus belajar, tri hita karana

\begin{abstract}
The problem in this study was the low science learning outcomes of students seen from the results of UTS students who were classified as low. This study aims to determine the significant effect of the Learning Cycle learning model based on Tri Hita Karana on the science learning outcomes of fifth-grade students in Gugus IV Kecamatan Banjar Kabupaten Buleleng, academic year 2018/2019. The research design used was the Non-equivalent Posttest-Only Control Group Design. The study population was all fifth-grade elementary school students in Gugus IV Kecamatan Banjar, amounting to 166 people. The sample is taken by a random sampling technique. The sample of this study was the fifth-grade students of SD Negeri 8 Banjar, which amounted to 28 people as the experimental group and the fifth-grade students of SD Negeri 1 Banjar which amounted to 24 people as the control group. Learning outcomes data were collected using multiple choice tests and attitude assessments using observation sheets. The data obtained were analyzed using descriptive statistics and inferential statistics (t-test). The results of the t-test analysis of learning outcomes show that $t_{\text {count }}$ is $4.92,, t_{\text {table }}$ at the 0.05 significance level of 2.00 . The results showed that there was a significant effect of the Tri Hita Karana based learning cycle learning model on science learning outcomes of fifth-grade students in Gugus IV Kecamatan Banjar Kabupaten Buleleng academic year 2018/2019.
\end{abstract}

Key words : learning outcomes, learning cycle, tri hita karana 
Sang Ayu Putu Indrayani, I Gst. Ngurah Japa ,Ni Wayan Arini. (2019). Jurnal Pendidikan Multikultural Indonesia. Vol. 2 (2) pp. 76-86.

\section{PENDAHULUAN}

Pendidikan merupakan usaha sadar yang dapat dilakukan untuk meningkatkan kualitas sumber daya manusia. Untuk meningkatkan kualitas sumber daya manusia diperlukan suatu usaha nyata dan terencana dari pemerintah. Salah satu usaha yang dilakukan pemerintah saat ini adalah memperbaiki kualitas pendidikan yaitu dengan penyempurnaan kurikulum. Prastowo (2013:193) menyatakan bahwa "kurikulum adalah subsistem dalam dunia pendidikan yang tidak bisa dipisahkan dari proses dinamika yang terjadi di dalam masyarakat". Secara sederhana berdasarkan pendapat tersebut kurikulum merupakan seperangkat komponen yang sangat penting dalam dunia pendidikan. Oleh karena itu, kurikulum harus mampu mempersiapkan para peserta didik di dalam menghadapi tantangan masa depan yang terus berubah. Tantangan masa depan yang terus berubah inilah, yang menjadi sorotan bagi Indonesia untuk memperbaiki mutu pendidikan yang lebih baik salah satunya dengan cara penyempurnaan kurikulum.

Beberapa kurikulum pernah berlaku di Indonesia salah satunya adalah kurikulum tingkat satuan pendidikan 2006. Prastowo (2013:204) menyatakan bahwa "kurikulum tingkat satuan pendidikan yang disingkat KTSP merupakan kurikulum yang berorientasi pada pencapaian kompetensi". Ciri yang menonjol pada KTSP 2006 terletak pada kegiatan inti yaitu menggunakan metode yang disesuaikan dengan karakteristik peserta didik dan mata pelajaran, yang dapat meliputi proses eksplorasi, elaborasi dan konfirmasi (EEK). Dalam KTSP 2006 untuk SD/MI memuat delapan mata pelajaran salah satunya adalah IPA. IPA merupakan ilmu yang mempelajari tentang alam. Menurut Hendro Darmojo IPA adalah pengetahuan yang rasional dan objektif tentang alam semesta dengan segala isinya (dalam Samatowa,2010).

Berdasarkan pengertian IPA tersebut adapun tujuan pembelajaran sains (IPA) di sekolah dasar salah satunya mengembangkan rasa ingin tahu, sikap positif dan kesadaran tentang adanya hubungan yang saling memengaruhi antara IPA, lingkungan, teknologi, dan masyarakat serta meningkatkan kesadaran untuk menghargai alam dan segala keteraturannya sebagai salah satu ciptaan Tuhan. Secara tidak langsung di dalam IPA peserta didik diajarkan mengenai nilai - nilai agama. Salah satunya menghargai alam beserta isinya sebagai ciptaan Tuhan agar nantinya tercipta suatu hubungan yang harmonis antara semua makhluk dengan penciptaNya. Konsep hubungan yang harmonis antara semua makhluk dengan penciptaNya sudah tidak asing lagi dikenal khususnya bagi masyarakat di Bali. Konsep ini dikenal dengan nama "Tri Hita Karana". Tri Hita Karana merupakan salah satu budaya lokal yang terdapat di Bali, yang mengemukakan tentang hubungan baik manusia dengan Tuhan, sesama manusia, dan lingkungan tempat tinggalnya. Tri Hita Karana berasal dari kata "Tri" yang berarti tiga, " Hita" yang berarti kebahagiaan dan "Karana" yang berarti penyebab. Dengan demikian Tri Hita Karana berarti "Tiga penyebab terciptanya kebahagiaan". Konsep Tri Hita Karana ini mengajarkan manusia untuk senantiasa menjaga keharmonisan di dunia mulai dari diri sendiri dan segala sesuatu yang ada di sekitarnya. Pada dasarnya, hakikat ajaran Tri Hita Karana menurut Wiana menekankan pada tiga hubungan manusia dalam kehidupan di dunia ini. Ketiga hubungan itu meliputi hubungan dengan sesama manusia, hubungan dengan alam sekeliling, dan hubungan dengan Tuhan yang saling terkait satu sama lain. Setiap hubungan memiliki pedoman hidup menghargai sesama aspek sekelilingnya (dalam Subagia, 2016).

Dewasa ini dapat kita rasakan sendiri telah terjadi ketidakharmonisan terutama hubungan antara manusia dengan Tuhan, hubungan manusia dengan manusia dan hubungan manusia dengan lingkungannya. Salah satunya hal yang biasa paling terlihat adalah hubungan antara siswa dengan siswa yang lainnya kurang terjalin dengan baik, ada beberapa siswa yang tidak saling bicara dengan temannya. Ini artinya sikap sosial yang dimiliki oleh siswa masih kurang yang jika dikaitkan dengan konsep Tri Hita Karana mengena pada konsep pawongan. Ketiga konsep ini saling keterkaitan antara satu dengan yang lainnya. Salah satu dari ketiga konsep ini tidak berjalan maka keharmonisan di dalam hidup yang dimaksud tidak akan tercapai. Terlebih lagi, konsep ini merupakan suatu budaya lokal yang sangat melekat pada masyarakat Bali yang perlu dilestarikan. Melalui penanaman konsep Tri Hita Karana diharapkan mampu memberikan perubahan sikap yang lebih baik dari dalam diri siswa guna menciptakan suatu keharmonisan dalam hidup.

Berdasarkan hasil observasi yang telah dilakukan pada tanggal 9 Januari 2019 di SD gugus IV Kecamatan Banjar, ditemukan permasalahan diantaranya: 1) dalam proses pembelajaran IPA di

Pengaruh Model Pembelajaran Siklus Belajar Berbasis Trihita Karana Terhadap Hasil Belajar Ipa Siswa Kelas V Di Gugus Iv Kecamatan Banjar 
kelas guru kurang melakukan kegiatan pembelajaran dengan memfokuskan pada pengembangan keterampilan proses sains anak, 2) guru hanya cukup terfokus pada satu model tanpa perlu mencoba menerapkan model-model pembelajaran yang lain, 3) jarang ditemukan siswa yang mengacungkan tangan untuk bertanya atau mengemukakan pendapatnya. Hal tersebut disebabkan kurangnya pemahaman siswa terhadap materi yang telah diajarkan oleh guru sehingga siswa merasa enggan untuk berbicara.

Permasalahan-permasalahan di atas diperkuat dengan hasil wawancara yang dilakukan dengan guru kelas V SD di Gugus IV Kecamatan Banjar pada tanggal 14 Januari 2019 guru menyampaikan bahwa 1) siswa kurang bersemangat dalam mengikuti pembelajaran hal ini karena pembelajaran hanya berdasarkan buku pegangan tanpa terfokus pada pengembangan proses sains anak, 2) kurangnya perhatian siswa terhadap pemaparan materi yang disampaikan oleh guru, 3) terdapat beberapa siswa yang tidak berperan aktif mengikuti pembelajaran dikarenakan tidak semua siswa dapat memahami materi pelajaran dengan baik. Permasalahan di atas secara tidak langsung memengaruhi hasil belajar siswa.

Selain hasil observasi dan wawancara, diperkuat juga dengan hasil pencatatan dokumen hasil UTS IPA siswa kelas V di SD Gugus IV Kecamatan Banjar, dengan rata-rata hasil belajar yang masih tergolong rendah. Dapat dilihat pada tabel 1 berikut ini.

\section{Tabel 1.}

Rata-rata nilai UTS IPA Siswa Kelas V di Gugus IV Kecamatan Banjar.

\begin{tabular}{|c|c|c|c|c|c|c|c|c|}
\hline \multirow[t]{2}{*}{ No } & \multirow[t]{2}{*}{ Sekolah } & \multirow{2}{*}{$\begin{array}{l}\text { Jumlah } \\
\text { Siswa }\end{array}$} & \multirow{2}{*}{$\begin{array}{l}\text { Rata - rata } \\
\text { nilai UTS }\end{array}$} & \multirow[t]{2}{*}{ KKM } & \multicolumn{2}{|c|}{$\begin{array}{c}\text { Siswa yang } \\
\text { mencapai KKM }\end{array}$} & \multicolumn{2}{|c|}{$\begin{array}{c}\text { Siswa yang tidak } \\
\text { mencapai KKM }\end{array}$} \\
\hline & & & & & Siswa & $\%$ & Siswa & $\%$ \\
\hline 1 & SD Negeri 1 Banjar & 24 & 61,04 & 65 & 11 & 46 & 13 & 54 \\
\hline 2 & SD Negeri 3 Banjar & 15 & 59,80 & 60 & 10 & 67 & 5 & 33 \\
\hline 3 & SD Negeri 5 Banjar & 17 & 58,35 & 65 & 7 & 41 & 10 & 59 \\
\hline 4 & SD Negeri 6 Banjar & 12 & 57,25 & 60 & 7 & 58 & 5 & 42 \\
\hline 5 & SD Negeri 7 Banjar & 24 & 55,67 & 60 & 4 & 17 & 20 & 83 \\
\hline 6 & SD Negeri 8 Banjar & 28 & 60,32 & 62 & 10 & 36 & 18 & 64 \\
\hline 7 & SD Negeri 9 Banjar & 35 & 56,86 & 60 & 14 & 40 & 21 & 60 \\
\hline 8 & SD Negeri 10 Banjar & 11 & 55,18 & 60 & 5 & 45 & 6 & 55 \\
\hline \multicolumn{5}{|c|}{ Jumlah } & 68 & 350 & 98 & 450 \\
\hline
\end{tabular}

(Sumber: Tata Usaha SD di Gugus IV Kecamatan Banjar, 2018).

Berdasarkan tabel tersebut, tampak bahwa rata-rata nilai siswa kelas $\mathrm{V}$ masih berada di bawah KKM. Dengan presentase siswa yang mencapai KKM sebanyak 68 orang dan sebanyak 98 orang siswa yang tidak mencapai KKM. Ini artinya masih banyak siswa yang berada di bawah $\mathrm{KKM}$, sehingga perlu adanya suatu usaha untuk memperbaiki kendala tersebut. Untuk mengatasi permasalahan tersebut, diperlukan inovasi dari guru untuk mengemas pembelajaran IPA agar pembelajaran IPA dapat digemari oleh siswa. Salah satu inovasi model pembelajaran yang dapat digunakan agar siswa dapat ikut terlibat aktif dalam proses pembelajaran, sehingga berdampak pada peningkatan hasil belajar IPA siswa kelas V SD di gugus IV Kecamatan Banjar adalah menggunakan model pembelajaran Siklus Belajar.

Model Siklus Belajar adalah modell pembelajaran yang berlandaskan pada pandangan konstruksivisme yang tentunya berpusat pada siswa (student centered). Teori kontruktivisme memandang bahwa pengetahuan itu berasal dari luar akan tetapi dikontruksi dari dalam diri seseorang. Pembelajaran konstruktivisme pada dasarnya menekankan pentingnya peserta didik membangun sendiri pengetahuan mereka melalui keterlibatan dalam proses belajar mengajar. Ciri khas model pembelajaran siklus belajar adalah setiap siswa secara individu belajar materi pembelajaran yang sudah dipersiapkan guru. Kemudian, hasil belajar individual dibawa ke kelompok - kelompok untuk didiskusikan oleh anggota kelompok dan semua anggota kelompok 
Sang Ayu Putu Indrayani, I Gst. Ngurah Japa ,Ni Wayan Arini. (2019). Jurnal Pendidikan Multikultural Indonesia. Vol. 2 (2) pp. 76-86.

bertanggung jawab secara bersama - sama atas keseluruhan jawaban. Menurut Piaget model pembelajaran siklus belajar pada dasarnya memiliki lima fase yang disebut (5E) yaitu Engagement, Exploration, Explaination, Elaboration, dan Evaluation (dalam Aris Shoimin,2014). Pada tahap engagement minat dan keingintahuan (curiosity) pembelajar tentang topik yang akan diajarkan berusaha dibangkitkan. exploration siswa diberi kesempatan berinkuiri dengan melibatkan seluruh panca indranya untuk berinteraksi dengan lingkungan dan objek yang dipelajarinya, explaination pembelajar menemukan istilah - istilah dari konsep yang dipelajari elaboration siswa diajak untuk menerapkan pemahaman konsepnya yang baru melalui kegiatan pemecahan masalah terhadap masalah - masalah yang nyata dalam kehidupan siswa, dan evaluation yaitu evaluasi terhadap efektifitas tahap-tahap sebelumnya dan juga evaluasi terhadap pengetahuan, pemahaman konsep, atau kompetensi siswa melalui problem solving dalam konteks baru yang kadang-kadang mendorong siswa melakukan investigasi lebih lanjut.

Perpaduan antara model pembelajaran Siklus Belajar berbasis tri hita karana terlihat pada saat pembelajaran berlangsung. Implementasi tri hita karana unsur parhyangan terlihat pada saat guru dan siswa melaksanakan persembahyangan atau berdoa saat mengawali dan mengakhiri pembelajaran. Sedangkan implementasi unsur pawongan terlihat pada saat proses pembelajaran yaitu pada saat siswa berdiskusi dengan kelompoknya dan melaksanakan tanya jawab dengan guru serta siswa lainnya. Selanjutnya, implementasi unsur palemahan terlihat pada saat guru dan siswa melaksanakan pembersihan lingkungan kelas saat mengawali dan mengakhiri pembelajaran. Dengan penggunaan model pembelajaran Siklus Belajar berbasis Tri Hita Karana ini diharapkan budaya lokal yang terdapat di Bali hendaknya ditanamkan sejak dini. Perlunya penanaman budaya lokal sejak dini dilakukan karena seseorang sangat mudah dibentuk kepribadiannya dari sejak dini agar budaya lokal yang telah ada tidak dilupakan begitu saja.

Berdasarkan hal tersebut maka peneliti ingin mengakaji pengaruh model pembelajaran Siklus Belajar berbasis Tri Hita Karana terhadap hasil belajar IPA siswa kelas V melalui suatu penelitian yang berjudul "Pengaruh Model Pembelajaran Siklus Belajar Berbasis Tri Hita Karana Terhadap Hasil Belajar IPA Siswa kelas V SD Gugus IV Kecamatan Banjar Kabupaten Buleleng Tahun Pelajaran 2018/2019".

Tujuan penelitian ini adalah mengetahui pengaruh model pembelajaran Siklus Belajar berbasis Tri Hita Karana terhadap hasil belajar IPA siswa kelas V SD di Gugus IV Kecamatan Banjar Kabupaten Buleleng tahun pelajaran 2018/2019.

\section{METODE}

Jenis penelitian ini adalah penelitian eksperimen semu (Quasi Eksperiment). Desain penelitian ini menggunakan Non Equivalent Post-test Only Control Group Design. Desain ini menggunakan 2 kelompok yaitu kelas eksperimen dan kelas kontrol. Kelas eksperimen adalah kelompok yang diberikan perlakuan dengan menerapakan model pembelajaran siklus belajar, sedangkan kelompok kelas kontrol adalah kelompok pengendali yaitu kelas yang tidak mendapat perlakuan. Populasi dalam penelitian ini adalah seluruh siswa kelas V SD di Gugus IV Kecamatan Banjar Kabupaten Buleleng yang berjumlah 166 orang siswa.

Teknik pemilihan sampel dalam penelitian ini adalah simple random sampling, yaitu pengambilan sampel anggota populasi secara acak tanpa memperhatikan strata yang ada. Pemilihan sampel secara acak ini dilakukan melalui sistem undian. Nama SD di Gugus IV yang menerapkan KTSP di tulis dalam kertas - kertas kecil. Kertas - kertas kecil tersebut digulung. Dari gulungan kertas tersebut, kemudian dipilih dua gulungan secara acak. Dua gulungan yang dipilih secara acak tersebut akan dijadikan sampel penelitian. Dari hasil random yang dilakukan tersebut, SD yang terpilih adalah SD Negeri 8 Banjar dan SD Negeri 1 Banjar. Sampel yang ditetapkan dalam penelitian ini adalah siswa kelas V SD Negeri 8 Banjar yang berjumlah 28 siswa dan kelas V SD Negeri 1 Banjar berjumlah 24 siswa. Total seluruh sampel adalah 52 siswa.

Metode yang digunakan untuk mengumpulkan data dalam penelitian ini adalah dengan menggunakan tes untuk hasil belajar aspek kognitif dan lembar observasi digunakan untuk mengumpulkan data tentang sikap siswa. Tes yang digunakan adalah tes hasil belajar IPA berupa tes pilihan ganda. Tes tersebut terdiri dari 30 butir soal. Soal yang digunakan untuk post-test sebelumnya telah di uji judges, kemudian diuji cobakan. Uji coba tes hasil belajar IPA meliputi, uji 
validitas butir, uji reliabilitas tes, uji daya beda dan uji tingkat kesukaran. Selanjutnya penilaian sikap ini dilakukan untuk mengetahui berhasil atau tidaknya pengaplikasian Tri Hita Karana dalam proses pembelajaran dengan menggunakan lembar observasi. Lembar observasi digunakan untuk mengumpulkan data tentang sikap siswa dalam pembelajaran yang mengguanakn model pembelajaran Siklus Belajar berbasis Tri Hita Karana. Observasi penilaian sikap dalam penelitian ini dengan menggunakan rubrik penilaian sikap. Aspek sikap yang digunakan diambil dari indikator yang sesuai dengan Tri Hita Karana.

Penelitian ini menggunakan dua metode analisis data yaitu metode analisis statistik deskriptif dan statistik inferensial. Metode analisis data yang digunakan untuk menguji hipotesis dalam penelitian ini adalah Uji-t sampel independent (tidak berkolerasi). Sebelum dilakukan uji hipotesis dengan metode statistika tersebut, terlebih dahulu dilakukan uji prasyarat analisis yang meliputi uji normalitas sebaran data dengan menggunakan Chi-Kuadrat, dan uji homogenitas varians dengan menggunakan uji Fisher.

\section{HASIL DAN PEMBAHASAN}

Dari hasil penelitian terhadap 28 orang siswa yang dibelajarkan dengan model pembelajaran siklus belajar berbasis tri hita karana diperoleh skor tertinggi adalah 30 dan skor terendah adalah 13. Untuk mempermudah dalam mendeskripsikan data hasil post test IPA pada kelompok eksperimen terlebih dahulu data tersebut harus disajikan ke dalam tabel distribusi frekuensi.

Data yang disajikan ke dalam tabel distribusi frekuensi terlebih dahulu harus ditentukan banyak kelas, rentangan (range), dan panjang kelas interval. Berdasarkan hasil penghitungan, maka ditetapkan banyak kelas adalah 6 dan panjang kelas adalah 3. Distribusi frekuensi data hasil belajar IPA kelompok eksperimen disajikan pada tabel 2.

Tabel 2

Distribusi Frekuensi Data Hasil Post- test Kelompok Eksperimen

\begin{tabular}{ccccc}
\hline & & $\begin{array}{c}\text { Titik } \\
\text { No }\end{array}$ & $\begin{array}{c}\text { Frekuensi } \\
\text { Absolut } \\
(\mathrm{f})\end{array}$ & $\begin{array}{c}\text { Frekuensi } \\
\text { Komulatif }\end{array}$ \\
\hline 1 & $13-15$ & 14 & 1 & 28 \\
2 & $16-18$ & 17 & 3 & 27 \\
3 & $19-21$ & 18 & 7 & 24 \\
4 & $22-24$ & 23 & 7 & 17 \\
5 & $25-27$ & 26 & 8 & 10 \\
6 & $28-30$ & 29 & 2 & 2 \\
& Jumlah & & 28 & \\
\hline
\end{tabular}

Berdasarkan tabel distribusi frekuensi yang telah dibuat, maka dapat dilakukan penghitungan mean (M), median (Me), modus (Mo), standar deviasi (SD) dan varians $\left(\mathrm{S}^{2}\right)$. Setelah dilakukan penghitungan skor mean (M) yaitu 22,57 skor median (Me) yaitu 24,13, skor modus (Mo) yaitu 27,07, standar deviasi (SD) yaitu 3,72 dan varians $\left(S^{2}\right)$ yaitu 13,84. Data hasil Post-test kelompok eksperimen kemudian disajikan ke dalam grafik polygon seperti pada gambar 1. 
Gambar 1.

Kurva Polygon Data Post -test Kelompok Esperimen

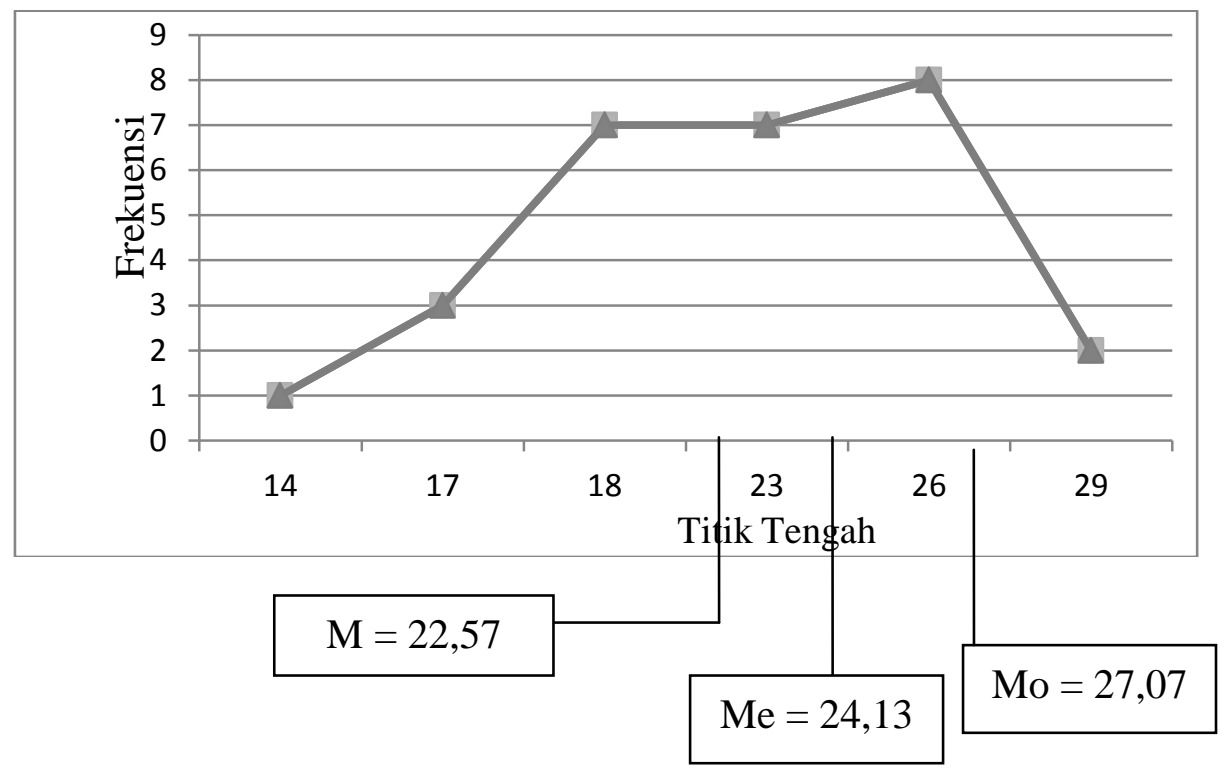

Berdasarkan nilai Mo $>\mathrm{Me}>\mathrm{M}(27,07>24,13>22,57)$ dapat diketahui bahwa sebagian besar skor hasil belajar IPA kelompok siswa yang dibelajarkan dengan menggunakan model pembelajaran siklus belajar berbasis tri hita karana cenderung tinggi. Untuk mengetahui kualitas dari variabel hasil belajar IPA siswa, skor rata-rata hasil belajar IPA siswa dikonversikan dengan menggunakan kriteria rata-rata ideal (MI) dan standar deviasi ideal (SDi) sehingga di dapatkan skor rata-rata hasil belajar siswa kelompok eksperimen adalah 22,57. Berdasarkan hasil konversi, dapat dinyatakan bahwa rata-rata hasil belajar IPA kelompok eksperimen termasuk dalam kategori sangat tinggi.

Selanjutnya, dari hasil penelitian dari 24 orang siswa yang dibelajarkan tanpa menggunakan model pembelajaran siklus belajar berbasis tri hita karana diperoleh skor tertinggi adalah 27 dan skor terendah adalah 10. Untuk mempermudah dalam mendeskripsikan data hasil post test hasil belajar IPA pada kelompok kontrol terlebih dahulu data tersebut harus disajikan ke dalam tabel distribusi frekuensi. Data yang disajikan ke dalam tabel distribusi frekuensi terlebih dahulu harus ditentukan banyak kelas, rentangan (range), dan panjang kelas interval.

Berdasarkan hasil penghitungan, maka ditetapkan banyak kelas adalah 6 dan panjang kelas adalah 3. Distribusi frekuensi data hasil belajar IPA kelompok kontrol disajikan pada tabel 3.

Tabel 3

Distribusi Frekuensi Data Hasil Post- test Kelompok Kontrol

\begin{tabular}{|c|c|c|c|c|}
\hline \multirow[b]{3}{*}{ No } & \multirow[b]{3}{*}{ Interval } & \multicolumn{3}{|c|}{ Frekuensi } \\
\hline & & Titik & Absolut & Frekuensi \\
\hline & & Tengah & $(f)$ & Komulatif \\
\hline 1 & $10-12$ & 11 & 1 & 24 \\
\hline 2 & $13-15$ & 14 & 3 & 23 \\
\hline 3 & $16-18$ & 15 & 13 & 20 \\
\hline 4 & $19-21$ & 20 & 4 & 7 \\
\hline 5 & $22-24$ & 21 & 2 & 3 \\
\hline \multirow[t]{2}{*}{6} & $25-27$ & 26 & 1 & 1 \\
\hline & Jumlah & & 24 & \\
\hline
\end{tabular}

Pengaruh Model Pembelajaran Siklus Belajar Berbasis Trihita Karana Terhadap Hasil Belajar Ipa Siswa Kelas V Di Gugus Iv Kecamatan Banjar 
Berdasarkan tabel distribusi frekuensi yang telah dibuat maka dapat dilakukan penghitungan mean (M), median (Me), modus (Mo), standar deviasi (SD) dan varians $\left(\mathrm{S}^{2}\right)$. Setelah dilakukan penghitungan skor mean (M) yaitu 17,75 skor median (Me) yaitu 17,46, skor modus (Mo) yaitu 16,92 , standar deviasi (SD) yaitu 3,15 dan varians $\left(S^{2}\right)$ yaitu 9,90 . Data hasil Post-test kelompok kontrol kemudian disajikan ke dalam grafik polygon seperti pada gambar 2 .

Gambar 2

Kurva Polygon Data Post -test Kelompok Kontrol

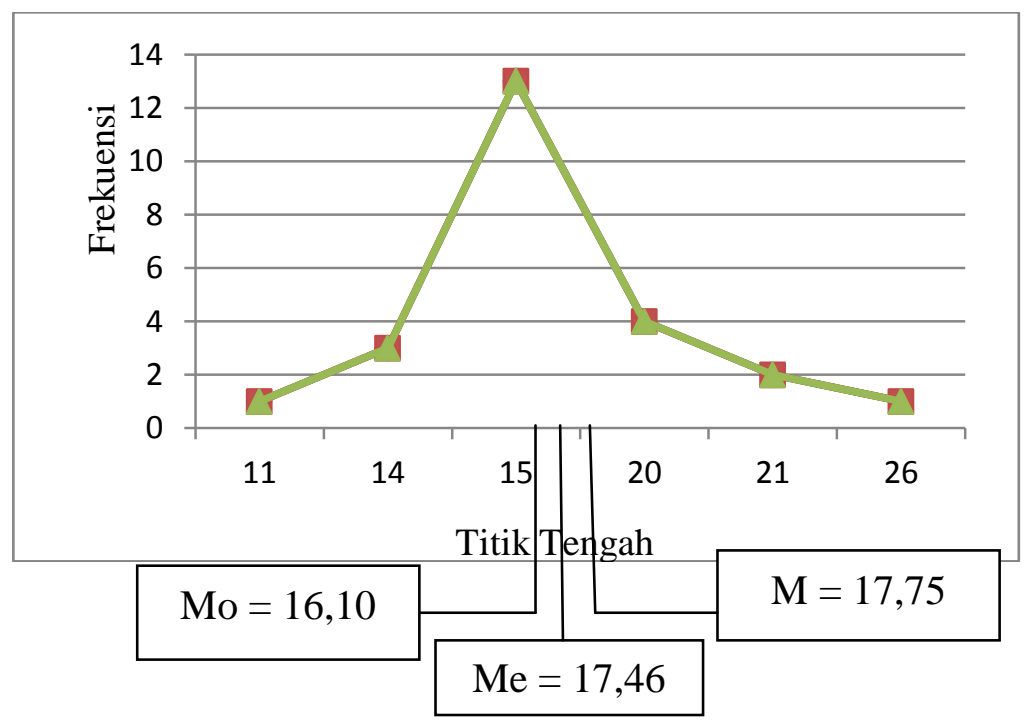

Berdasarkan nilai $\mathrm{Mo}<\mathrm{Me}<\mathrm{M}(16,10>17,46>17,75)$ tersebut diketahui bahwa sebagian besar skor hasil belajar IPA kelompok siswa yang dibelajarkan tanpa menggunakan model pembelajaran siklus belajar berbasis tri hita karana cenderung rendah. Untuk mengetahui kualitas dari variabel hasil belajar IPA siswa, skor rata-rata hasil belajar IPA siswa dikonversikan dengan menggunakan kriteria rata-rata ideal (MI) dan standar deviasi ideal (SDi) sehingga di dapatkan skor rata-rata hasil belajar siswa kelompok kontrol adalah 17,75. Berdasarkan hasil konversi, dapat dinyatakan bahwa rata-rata hasil belajar IPA kelompok kontrol termasuk dalam kategori tinggi.

Berdasarkan hasil penghitungan dengan menggunakan rumuas chi-square, diperoleh hasil $X^{2}$ hitung kelompok eksperimen adalah 9,37 dan $X_{\text {tabel }}^{2}$ dengan taraf dignifikansi $5 \%$ dan $\mathrm{db}=5$ adalah 11,07 . Hal ini berarti $X^{2}$ hitung lebih kecil dari $X^{2}$ tabel $\left(X^{2}\right.$ hitung $<X^{2}$ tabel $)$ sehingga data hasil belajar IPA kelompok eksperimen berdistribusi normal. Sedangkan untuk data hasil belajar IPA kelompok kontrol diperoleh $X^{2}$ hitung adalah 6,24 dan $X_{\text {tabel }}^{2}$ dengan taraf signifikansi $5 \%$ dan db = 5 adalah 11,07 . Hal ini berarti, $X^{2}$ nitung lebih kecil dari $X^{2}$ tabel $\left(X^{2}\right.$ hitung $<X^{2}$ tabel $)$ sehingga data hasil belajar IPA kelompok kontrol berdistribusi normal.

Uji homogenitas varians dilakukan untuk menguji perbedaan yang terjadi pada kedua kelompok antara kelompok eksperimen dan kelompok kontrol benar - benar berasal dari perbedaan perlakuan yang diberikan, bukan akibat dari perbedaan yang terjadi dalam kelompok. Pengujian homogenitas varians antar kelompok pada penelitian ini dilakukan dengan menggunakan uji $F$ (Fisher) dengan kriteria pengujian, jika $F_{\text {hitung }} \geq F_{\text {tabel }}$ dapat disimpulkan varians tidak homogen dan jika $F_{\text {hitung }}<F_{\text {tabel }}$, dapat disimpulkan varians homogen. Rangkuman hasil uji homogenitas disajikan pada tabel 4. 
Sang Ayu Putu Indrayani, I Gst. Ngurah Japa ,Ni Wayan Arini. (2019). Jurnal Pendidikan Multikultural Indonesia. Vol. 2 (2) pp. 76-86.

Tabel 4.

Hasil Uji Homogenitas Varians

\begin{tabular}{cccc}
\hline $\begin{array}{c}\text { Data } \\
\begin{array}{c}\text { Post -test Kelompok } \\
\text { Eksperimen dan Kelompok }\end{array}\end{array}$ & $\mathrm{F}_{\text {hitung }}$ & $\begin{array}{c}\mathrm{F}_{\text {tabel }} \\
(5 \%)\end{array}$ & Kesimpulan \\
Kontrol & 1,40 & 4,00 & Homogen \\
\hline
\end{tabular}

Berdasarkan tabel di atas, dapat diketahui bahwa hasil post test kelompok eksperimen dan kelompok kontrol dengan $\mathrm{db}$ pembilang $=28-1=27$ dan $\mathrm{db}$ penyebut $=24-1=23$ pada taraf signifikansi $5 \%$ diketahui $F_{\text {tabel }}=4,00$ dan $F_{\text {hitung }}=1,40$. Hal ini berarti bahwa $F_{\text {hitung }}<F_{\text {tabel }}$, sehingga dapat disimpulkan bahwa varians data hasil belajar IPA siswa kelompok eksperimen dan kelompok kontrol bersifat homogen.

Pengujian hipotesis penelitian dilakukan dengan uji-t sampel independent (tidak berkolerasi) dengan rumus polled varians. Kriteria pengujian hipotesis yang digunakan adalah $\mathrm{H}_{0}$ diterima jika $t$ hitung lebih kecil atau sama dengan $t$ tabel ( $\left.\mathrm{t}_{\text {hitung }} \leq \mathrm{t}_{\text {tabel }}\right)$, dan $\mathrm{H}_{0}$ ditolak jika harga $\mathrm{t}$ hitung lebih besar dari $t$ tabel $\left(t_{\text {hitung }}>t_{\text {tabel }}\right)$. Hasil uji-t sampel independent dengan rumus polled varians disajikan pada tabel 5 .

Tabel 5.

Rangkuman Hasil Uji-t Sampel Independent

\begin{tabular}{lcccccc}
\hline \multicolumn{1}{c}{ Sampel } & $\mathrm{N}$ & $\begin{array}{c}\text { Rata }- \\
\text { rata }\end{array}$ & $\begin{array}{c}\mathrm{S}_{2} \\
(\text { Varians })\end{array}$ & $\begin{array}{c}\mathrm{Dk} \\
\left(\mathrm{n}_{1}+\mathrm{n}_{2}\right)\end{array}$ & $\mathrm{t}_{\text {hitung }}$ & $\mathrm{t}_{\text {tabel }}$ \\
$\begin{array}{l}\text { Kelompok } \\
\text { Eksperimen }\end{array}$ & 28 & 22,57 & 13,84 & 50 & 4,92 & 2,00 \\
Kelompok Kontrol & 24 & 17,75 & 9,90 & & & \\
\hline
\end{tabular}

Berdasarkan hasil penghitungan menggunakan uji-t sampel independent dengan rumus polled varians diperoleh $t_{\text {hitung }}$ adalah 4,92 dan $t_{\text {tabel }}$ pada taraf signifikansi $5 \%$ dan db (28+24-2) $=$ 50 adalah 2,00. Hal ini berarti, $t_{\text {hitung }}$ lebih besar dari $t_{\text {tabel }}\left(t_{\text {hitung }}>t_{\text {tabel }}\right)$, sehingga $\mathrm{H}_{0}$ ditolak dan $\mathrm{H}_{1}$ di terima. Berdasarkan analisis tersebut, dapat diintrepretasikan bahwa terdapat pengaruh yang signifikan model pembelajaran siklus belajar berbasis tri hita karana terhadap hasil belajar IPA siswa kelas V SD di Gugus IV Kecamatan Banjar Kabupaten Buleleng tahun Pelajaran 2018/2019.

Berdasarkan penelitian yang telah dilakukan pada kelompok eksperimen dan kelompok kontrol terdapat beberapa hal yang ditemukan diantaranya sebagai berikut.

Pertama, setelah dilakukan analisis data terdapat perbedaan yang signifikan hasil belajar IPA antara siswa yang dibelajarkan dengan menggunakan model pembelajaran siklus belajar berbasis tri hita karana dengan siswa yang dibelajarkan tanpa menggunakan model pembelajaran siklus belajar berbasis tri hita karana. Secara deskriptif, hasil belajar siswa pada kelompok eksperimen lebih tinggi dibandingkan dengan hasil belajar pada kelompok kontrol. Hal ini disebabkan oleh kegiatan pembelajaran pada model siklus belajar memberikan pengalaman belajar kepada siswa dalam mengkonstruksi dan mengembangkan pengetahuan yang dimiliki siswa. Dalam pengalaman belajar ini, peserta didik diberikan kesempatan membangun sendiri pengetahuan mereka lewat keterlibatan dalam proses belajar mengajar. Guru dalam hal ini hanya berperan sebagai fasilitator dalam pembelajaran. Hal ini sejalan dengan pendapat Sadia (2014:19) Model siklus belajar ini mempunyai tujuan yang memberikan kesempatan kepada siswa untuk mengkonstruksi pengetahuan dan pengalaman mereka sendiri dengan terlibat secara aktif mempelajari materi secara bermakna dengan bekerja dan berpikir baik secara individu maupun kelompok, sehingga siswa dapat menguasai kompetensi-kompetensi yang harus dicapai dalam pembelajaran.

Pengaruh Model Pembelajaran Siklus Belajar Berbasis Trihita Karana Terhadap Hasil Belajar Ipa Siswa Kelas V Di Gugus Iv Kecamatan Banjar 
Kedua, terdapat perubahan sikap yang terjadi pada kelompok siswa yang dibelajarkan dengan menggunakan model pembelajaran siklus belajar berbasis Tri Hita Karana. Perubahan sikap yang terjadi yakni pada unsur parhyangan siswa menjadi terbiasa dan khusuk berdoa sebelum dan setelah proses pembelajaran. Pada unsur pawongan siswa yang pada awalnya jarang mau berinteraksi dengan teman lainnya, menjadi pribadi yang supel dan perlahan mau berinteraksi serta saling menghargai perbedaan pendapat dengan temanya. Pada unsur palemahan siswa menjadi lebih perduli akan pentingnya menjaga kebersihan lingkungan sekitar. Perubahan sikap ini terjadi karena di dalam proses pembelajaran yang dilakukan selalu ditanamkan mengenai konsep Tri Hita Karana, mulai dari sebelum dan setelah pembelajaran dimulai siswa diajarkan untuk melaksanakan pembersihan di lingkungan sekolah serta menjaga lingkungan tetap bersih dengan cara tidak membuang sampah sembarangan (palemahan). Selanjutnya sebelum dan setelah melaksanakan pembelajaran siswa diajak untuk berdoa dan menghaturkan canang di setiap pelinggih yang terdapat di sekolah (parhyangan). Kemudian siswa diberi kesempatan untuk menyampaikan pendapatnya terkait pembelajaran yang dilaksanakan, dengan menggunakan kata - kata yang sopan tidak menyinggung perasaan orang lain serta menghargai setiap perbedaan pendapat yang ada agar tidak terjadi perpecahan. Selain itu siswa juga diberi kebebasan bekerjasama dengan kelompoknya dalam menyelesaikan permasalahan yang terdapat pada LKS (pawongan). Berdasarkan temuan di atas, dapat diketahui bahwa ketiga unsur yang terdapat pada konsep tri hita karana telah terlaksana dengan baik sehingga terciptanya suatu hubungan yang harmonis. Hal ini sejalan dengan penelitian yang dilakukan oleh Putra (2016) yang menyatakan bahwa dengan menanamkan nilai tri hita karana mampu menciptakan hubungan yang harmonis antara manusia dengan Tuhan, manusia dengan sesama manusia dan manusia dengan lingkungan sekitar. Adapun penelitian lain yang mendukung temuan tersebut adalah penelitian yang dilakukan Bestari (2013) yang menyatakan bahwa model pembelajaran learning cycle 7E dikaitkan dengan konsep Tri Hita Karana, yang terdiri dari parahyangan, palemahan, dan pawongan. Ketiga aspek tersebut sangat berkaitan erat di dalam kehidupan sehari-hari siswa. Dengan adanya variasi dalam pembelajaran yaitu pada sintaks model pembelajaran learning cycle 7E yang diselingi dengan penanaman konsep Tri Hita Karana, maka penyajian materi lebih variatif dan proses pembelajaran lebih bermakna.

Ketiga, siswa menjadi bersemangat dalam mengikuti pembelajaran karena pembelajaran yang dilaksanakan bermakna bagi siswa. Hal ini disebabkan oleh lima fase yang terdapat pada model pembelajaran siklus belajar. Model pembelajaran siklus belajar memiliki 5 fase yaitu Engagement, Exploration, Explaination, Elaboration, dan Evaluation. Dalam proses pembelajaran siswa diberikan kesempatan mengungkapkan ide, gagasan yang dimilikinya serta kebebasan bekerjasama dalam kelompok kecil dengan saling mengungkapkan pendapatnya masing - masing untuk menyelesaikan masalah yang terdapat pada LKS. Hal ini tidak akan membuat siswa menjadi tertekan, sehingga pembelajaran yang dilaksanakan menjadi bermakna bagi siswa. Selain itu, selama kegiatan pembelajaran siswa lebih aktif karena kegiatan pembelajaran menggunakan model pembelajaran siklus belajar ini melibatkan siswa secara langsung dalam proses pembelajaran. Hasil penelitian Kasuma Ditriguna (2013) yang menyatakan bahwa siswa diberikan kebebasan untuk mengungkapkan gagasan, ide-ide serta berdiskusi dengan kelompoknya mengenai suatu konsep-konsep yang diajarkan melalui pengalaman langsung, sehingga pembelajaran menjadi menyenangkan.

Penggunaan model pembelajaran siklus belajar berbasis tri hita karana dalam proses pembelajaran dapat berimplikasi terhadap siswa yaitu siswa menjadi bersemangat karena pembelajaran yang dilaksanakan bermakna bagi siswa dan suasana belajar menjadi menyenangkan serta hasil belajar siswa mengalami peningkatan. Hal ini karena siswa diberikan kesempatan untuk mengontruksikan pengetahuan yang dimilikinya serta bekerjasama dengan kelompok dalam menyelesaikan suatu permasalahan. Dengan diberikan kesempatan untuk mengontruksikan pengetahuan yang dimilikinya, siswa menjadi percaya diri dan lebih tertantang dalam mengerjakan setiap soal - soal yang terdapat di buku maupun yang diberikan oleh guru serta menyelesaikan masalah dalam kehidupan sehari - hari. Selain itu, penanaman konsep tri hita karana didalamnya dapat menjadikan hubungan antara manusia dengan Tuhan, sesama manusia dan manusia dengan lingkungan sekitar menjadi harmonis.

Pengaruh Model Pembelajaran Siklus Belajar Berbasis Trihita Karana Terhadap Hasil Belajar Ipa Siswa Kelas V Di Gugus Iv Kecamatan Banjar 
Dengan menerapkan model pembelajaran siklus belajar berbasis tri hita karana juga dapat berimplikasi terhadap guru yaitu guru memperoleh wawasan baru mengenai model pembelajaran inovatif lain yang dapat diterapkan dalam proses pembelajaran sehingga pembelajaran yang dilaksanakan dapat menyenangkan. Selain itu, penanaman budaya lokal sejak dini dapat dilakukan oleh guru guna melestarikan budaya lokal yang ada agar tidak punah. Kepala sekolah dapat meningkatkan partisipasinya untuk memberikan kebijakan penggunaan model pembelajaran siklus belajar berbasis tri hita karana dalam pembelajaran dan menjadikan ajaran konsep tri hita karana sebagai acuan dalam bertingkah laku guna menciptakan suatu hubungan yang harmonis. Selain itu, menyediakan perpustakaan dengan buku-buku ajar yang lebih relevan dalam mendukung materi pembelajaran, sehingga dapat digunakan oleh siswa maupun guru dalam proses pembelajaran.

\section{SIMPULAN}

Berdasarkan hasil pengujian hipotesis dan pembahasan, maka hasil penelitian menunjukkan bahwa terdapat pengaruh model pembelajaran Siklus Belajar berbasis Tri Hita Karana terhadap hasil belajar IPA siswa kelas V SD di Gugus IV Kecamatan Banjar Kabupaten Buleleng tahun pelajaran $2018 / 2019$. Hasil analisis menunjukkan bahwa $t_{\text {hitung }}$ sebesar 3,65 dan $t_{\text {tabel }}$ pada taraf signifikansi $5 \%$ dan db $(28+24-2)=50$ adalah 2,00 . Hal ini brarti nilai $t_{\text {hitung }}$ lebih besar dari $t_{\text {tabel }}$ $(3,65>2,00)$.

Selanjutnya diketahui bahwa skor rata - rata hasil belajar IPA kelompok eksperimen adalah 22,57 sedangkan kelompok kontrol adalah 17,75. Hal ini berarti bahwa skor rata - rata hasil belajar kelompok eksperimen yang dibelajarkan menggunakan model pembelajaran siklus belajar berbasis tri hita karana lebih tinggi dibandingkan dengan skor rata - rata hasil belajar kelompok kontrol. Selain itu, terjadi perubahan sikap pada siswa yang dibelajarkan dengan menggunkan model pembelajaran berbasis tri hita karana yaitu pada unsur parhyangan siswa menjadi terbiasa dan khusuk berdoa sebelum dan setelah proses pembelajaran. Sehingga model pembelajaran siklus belajar berbasis tri hita karana berpengaruh terhadap hasil belajar IPA siswa.

Berdasarkan hasil penelitian, dapat diajukan beberapa saran antara lain sebagai berikut. 1) siswa, agar lebih aktif dalam mengikuti pembelajaran dan dapat mengasah kemampuannya untuk menyelesaikan masalah yang ada dengan kemampuannya sendiri dengan menggali informasi yang tersedia, 2) guru, agar lebih mengembangkan pembelajaran dengan menggunakan berbagai macam model pembelajaran yang inovatif, khususnya dalam pelajaran IPA serta mengintegrasikannya dengan budaya lokal yang ada salah satunya konsep tri hita karana agar tidak terlupakan, 3) kepala sekolah, agar selalu mendukung penggunaan model pembelajaran yang inovatif khususnya dalam pembelajaran IPA dan mata pelajaran lain dalam upaya meningkatkan hasil belajar siswa, 4) peneliti lain, agar meneruskan penelitian ini agar mampu menjangkau masalah - masalah lain yang belum ditemukan dalam penelitian ini sehingga menjadi penelitian yang sempurna. Selain itu penelitian ini bisa digunakan sebagai bahan pertimbangan untuk perbaikan dan penyempurnaan penelitian yang akan dilaksanakan.

\section{DAFTAR PUSTAKA}

Ditriguna, Kusuma Arya (2013). Pengaruh Model Pembelajaran Learning Cycle 5e Terhadap Sikap Ilmiah Dan Hasil Belajar Ipa Siswa Kelas V SD Negeri 5 Pedungan. Mimbar PGSD Undiksha, 1(1).

Samatowa, Usman. 2010. Pembelajaran IPA di Sekolah Dasar. Jakarta:Indeks.

Sadia. 2014. Model - Model Pembelajaran Sains Kontruktivistik. Yogyakarta:Graha IImu.

Subagia, Wisesa. Persepsi Masyarakat Terhadap Konsep Tri Hita Karana Sebagai Implementasi Hukum Alam. Jurnal Universitas Pendidikan Lampung. 
Sang Ayu Putu Indrayani, I Gst. Ngurah Japa ,Ni Wayan Arini. (2019). Jurnal Pendidikan Multikultural Indonesia. Vol. 2 (2) pp. 76-86.

Shoimin, Aris. 2014. 68 Model Pembelajaran Inovatif Dalam Kurikulum 2013.Yogyakarta: ARRUZZ Media.

Prastowo, Andi. 2013. Pengembangan Bahan Ajar Tematik. Yogyakarta:DIVA Press.

Putra, Gustana Wesa. (2016). Pengaruh Model Pembelajaran Savi Bermuatan Tri Hita Karana Terhadap Hasil Belajar Ipa Siswa Kelas IV. Mimbar Pgsd Undiksha, 4(1) 